\title{
都市ごみステーション収集のモデル作成に関する研究 \\ STUDY ON MODELLING PROCEDURE OF STATION-TYPE-COLLECTION OF MUNICIPAL SOLID WASTE
}

\author{
松藤敏彦*・神山桂一**・田中信 寿*** \\ By Toshihiko MATSUTO, Keïchi KOYAMA and Nobutoshi TANAKA
}

\begin{abstract}
In order to analyze and synthesize the station-type-waste-collection system, the computer model is required. In this paper, the modeling procedures are discussed. By examining the characteristics of the whole model and system parameters, especially with regard to the effect on the computational fitness of the model to the actual system, the model is simplified and revised step by step. Consequently special considerations to the non-uniformity of the traffic conditions in the collection area improve the model's fitness remarkably. In addition the algorisms which enable the model to be adjusted to the change of the system conditions are presented, so that the model can be used in various situations.
\end{abstract}

Keywords: refuse collection, simulation model, station type collection

\section{1. はじめに}

都市ごみの収集輸送は, 最終処分に至る一連の処理の 最初の段階であるが，全ごみ処理費中の 6 ～割を占め るといわれるその費用の大きさは，ごみ処理における大 きな問題の 1 つに数えられる. 通常, 収集輸送作業は車 両を用いて行われるが, 用地確保難に伴う処理場の遠隔 化, 交通事情の悪化など, 作業の遂行に不利な状況が, 特に大都市において一般的になりつつあり, 作業の効率 向上による費用低減の必要性が高まっている. その解決 は, 一方で収集機材の改良といったハードウェア面に求 められるが, 作業の条件が一様でない広い地域の収集作 業を多数の収集車によって行うというシステムの複雑さ のために, 計算機を用いたシステム工学的検討により有 効な施策を見出せる可能性が大きい.

Quon ら ${ }^{1)}$ は各戸収集を対象に, 各家庭のごみ容器を 収集車まで運びごみを移し替えるのに必要な時間，収集 車の移動速度など，収集作業のパラメーターの值または 関数形を定め, さらに作業の進行を表現する判断アルゴ

* 正会員 工博 北海道大学助手 工学部衛生工学科 （０60 札幌市北区北 13 条西 8 丁目）

** 正会員 工博 北海道大学教授 工学部衛生工学科(同上)

*** 正会員 工博 北海道大学助教授 工学部衛生工学科 (同上)
リズムをプログラム化して収集車の 1 日の動きをシミュ レートするモデルを作成した。 それを用いて, 収集条件 を表わすパラメーターと, いくつかの収集効率の従属関 係を検討している. 同様のモデルによる研究に, 種々の 施策をコストやサービスの質（時間内に収集できるか否 か）で評価したものもある ${ }^{2), 3)}$.ごみ収集輸送システム のシミュレーションモデルの形は, 対象となる収集方式 が定まればおのずと限られ，その作成方法および結果は 同一の方式をとっている他システムに対しても, ある程 度の一般性をもつと考えられる. また, そこでの情報は 以後の研究のためにも有用なものであり,こうしたとこ ろに 1)〜3）の研究の意義がある.

しかし，日本の多くの都市ではステーション収集とい う, 欧米に例の少ない収集方式をとっており，これに対 するQuon らのようなアプローチはまだなされていな い. よって, その検討の価值は大きい. また, 現象記述 モデルの性格上,その精度が結果の信頼性を左右するが, 上記 1）～3）の研究ではモデルが実システムをよく表わ しているかどうかの確認が不十分のように思われる. モ デル化の過程においては実测值に基づいて精度を検討 し，それに応じてパラメーターの近似度を上げる工夫が 必要であり，その一方でモデルの簡略化をはかるために 不必要な複雑さを避けることも考慮すべきである. 
本研究は，以上の上うな観点に立ってステーション収 集のモデル作成，特に作成プロセスを中心に検討するも のである，収集計画を立てる際には，まず作業に要する 時間を推定することが必要で, それをもとに収集車台数 の決定や収集地域の割当てが行われる。そうのため, 最初 に収集車の作業時間を推定するモデル式を考え，実測值 との比較検討により推定精度に及ぼす影響の重要度に応 じてパラメーターの取捨を行い，式を修正していく，そ ののち, 作業時間の経過度合によって作業者の行動が変 わることを表わすアルゴリズムを考え，収集作業をシ ミュレートして収集車の収集区域を自動的に決定するモ デルを作成する．最後に計算例によって，その利用可能 性を示す。

\section{2. 作業時間推定モデル式の構成および対象地 域}

\section{（1）モデル式の構成}

まず, 1 台の収集車が清掃事務所, 収集現場, 清掃工 場の間を移動しながら，収集現場に排出された全ごみを 収集するのに要する時間をシミュレートすることを考え る．そのため，収集車の作業の流れを用語の定義ととも に図示すると，図一1のようになる，ここで“移動”と はステーション間の移動を指し，清掃事務所一収集現場 ～清掃工場相互間の移動は，ごみを積んでいないときの 回送も含めて“輸送”とよぶ。また，ステーションでの ごみ積込みの前後には，収集車への乗降，収集車の方向 転換のための時間が必要であるため,これを“準備”之 よぶ.

図一1では清掃事務所 $\rightarrow$ 収集現場 $\rightarrow$ 清掃工場 $\rightarrow$ 清掃 事務所という最も単純な場合を示しているが，実際には 1 日の作業でこれら相互の “輸送”を何度か行う. 昼食 のため, 収集後清掃事務所へ “輸送”することもある (図 -10 参照).
いま，移動，輸送などのおのおのを単位作業とよぶこ とにすれば，1台の収集車が 1 日の作業で各単位作業に

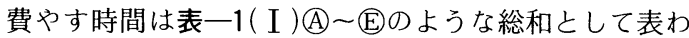
すことができる．さらにその総和が 1 日の合計作業時間 $T_{a a y}$ である. 表中, 各変数の添字は図一1の英名に対応 している，ただし，以下では清掃事務所〜収集現場，収 集現場～清掃工場，清掃工場～清掃事務所間の輸送を， それぞれ添字 $h l 1, h l 2, h l 3$ により区別するが，これ

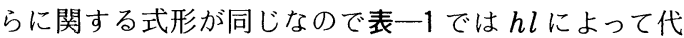
表している $\left(t_{h l}, d_{h l}, N_{h l}\right)$. 上つき添字 $j$ は，おのお のの作業回数に対応し，平均值等ではなくそれぞれ個々 に扱うことを示す，本論文のモデルで用いる記号を表一 2 にまとめておく.

表一1（Ｉ）の式群(A)（巨が本論文で用いるモデルの基 本形であり，モデル ( I ) とよぶ. 式中に含まれるパラ メーターは大きく次の 3 つに分類できる．すなわち， (a) 収集輸送作業に関係するもの(作業パラメーターとよぶ) で, $v_{h l}^{j}, v_{t s}^{j}, \tau_{p u}^{j}, t_{p r}^{j}, t_{d p}^{j}$ が含まれる，(b収集地域が決

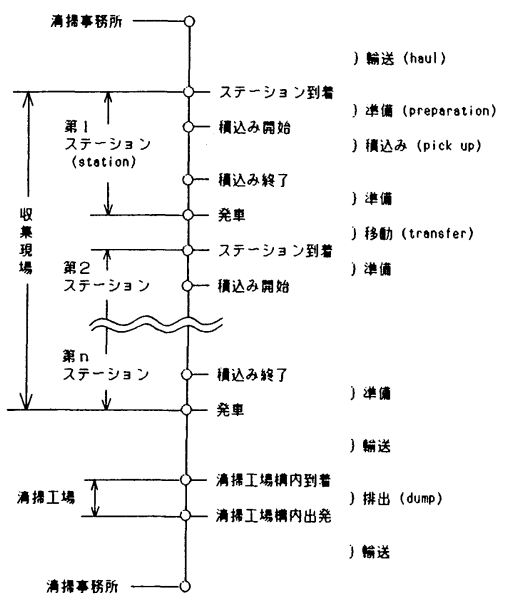

図一1 収集車の1日の作業

表一1 作業時間の算出式

\begin{tabular}{|c|c|c|c|c|c|}
\hline モデル & (A) $T_{n 11}, T_{n 12}$ & 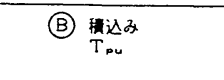 & (C) 移到 & (D) 藮铺 & (E) $\underset{\substack{\text { 排出 } \\
\text { ap }}}{\text { nap }}$ \\
\hline (1) & $\sum_{j}^{N_{n 1}} t_{n_{1}}=\sum_{j}^{N_{n 1}}\left(d_{n 1}^{j} / v_{n 1}^{J}\right)$ & 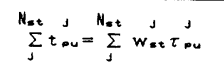 & $\sum_{j}^{N_{t f}} t_{t f}^{J}=\sum_{j}^{N_{t f}}\left(d_{t \in t}^{J} v_{t f}^{J}\right)$ & $\sum_{j}^{N_{2 t}} t_{\text {er }}$ & $\sum_{j}^{N a p} J_{\text {ap }}$ \\
\hline (I) & $N_{n 1} t_{n 1}=N_{n 1}\left(\tilde{d}_{n 1} / \hat{v}_{n 1}\right)$ & $\begin{aligned} N_{s t} t_{p u} & =N_{s t} \tilde{W}_{s t} \hat{\tau}_{p u} \\
& =W_{p u} \hat{\tau}_{\text {su }}\end{aligned}$ & $\begin{array}{l}N_{t+t} t_{t f}=N_{t+f}\left(\tilde{d}_{t f} / \hat{v}_{t f}\right) \\
{\left[\hat{v}_{t+f}=\dot{t}\left(\tilde{d}_{t f}\right)\right]}\end{array}$ & $N_{s t} \hat{t}_{\text {pr }}$ & $N_{\text {ap }} \hat{t}_{\text {ap }}$ \\
\hline$(\mathbb{\alpha} \alpha)$ & $\begin{array}{l}N_{n 1} \sum_{1}^{k}\left(\Delta x_{i-1,1} / v_{1-1,1}\right) \\
v_{1-1,1}=\left(\alpha_{1-1}+\alpha_{1}\right) / 2 v_{\max }\end{array}$ & (II)と同じ & $\begin{array}{l}N_{t f}\left(\tilde{d}_{t f} / \hat{v}_{t f}\right)(1+\beta) \\
{\left[\hat{v}_{t f}=f\left(\tilde{d}_{t+}\right)\right]}\end{array}$ & （付）と同じ & （【）と同じ \\
\hline$(I \alpha)$ & $\begin{array}{l}\sum_{J_{J 1}}^{N_{n}} \sum_{1}\left(\Delta x_{1-1,1}^{J} v_{1-1,1}^{J}\right) \\
v_{1-1,1}^{J}=\left(\alpha_{1-1}+\alpha_{1}\right) / 2 v_{\text {max }}\end{array}$ & （1）と同じ & $\sum_{j}^{N}\left(d_{t f f}^{j} / v_{t+f}^{J}\right)(1+\beta)$ & （１）と同じ & （）と同し \\
\hline
\end{tabular}

一日の作菜時回 $T_{\text {dav }}=T_{n 11}+T_{n 12}+T_{n 13}+T_{\text {nu }}+T_{t e}+T_{\text {er }}+T_{\text {de }}$ 
まると既知となるもので, $d_{h l}^{j}, d_{t f}^{j}, w_{s t}^{j}, N_{s t}$ が含まれる， (C輸送作業の回数に関係するもので， $N_{h l}, N_{d p}$ が含まれ る，の 3 者である.

当面は@以外のパラメーターは既知であるものとし， (a)パラメーターの值をよ゙う扱うかについて検討する. (c)の取り扱いについては, 5. で議論の対象とする.

\section{（2）モデル作成の対象地域}

モデル作成の対象としたのは S市 N区（人口約 20 万 人)であり，図一2にその地理的概要を示すＮ区では 23 台の回転板式パッカー車を用いて, 週 2 回可然ごみ を収集している，そのため，全収集地域は月木，火金， 水土収集の地域に分けられ，その中でおのおのの収集車 の受け持ち区域が決められている。この小区域のことを 以下では収集ブロックとよび，図一2にはそれが示され ている，ただし，作業の進行状況に応じて収集班が互い に応援し合うことがあるため，実際の収集区域と収集ブ ロックとは厳密には一致しない.

N区の南部は市中心部へと続いている，収集ブロック が広いところは人家がまばらであると考えてよい．収集 車の公称積載量は 4 トンで, 1 台当たりのクルー編成は 運転者を含めて 3 人である. 各収集車は 1 日に 2 - 回 $\mathrm{S}$ 清掃工場へ収集ごみの搬入を行う。車庫は $\mathrm{N}$ 清掃事務 所敷地内にある.

\section{（3）作業パラメーター値の実測}

前述の 3 種のパラメーターのうち, 対象地域が定まれ

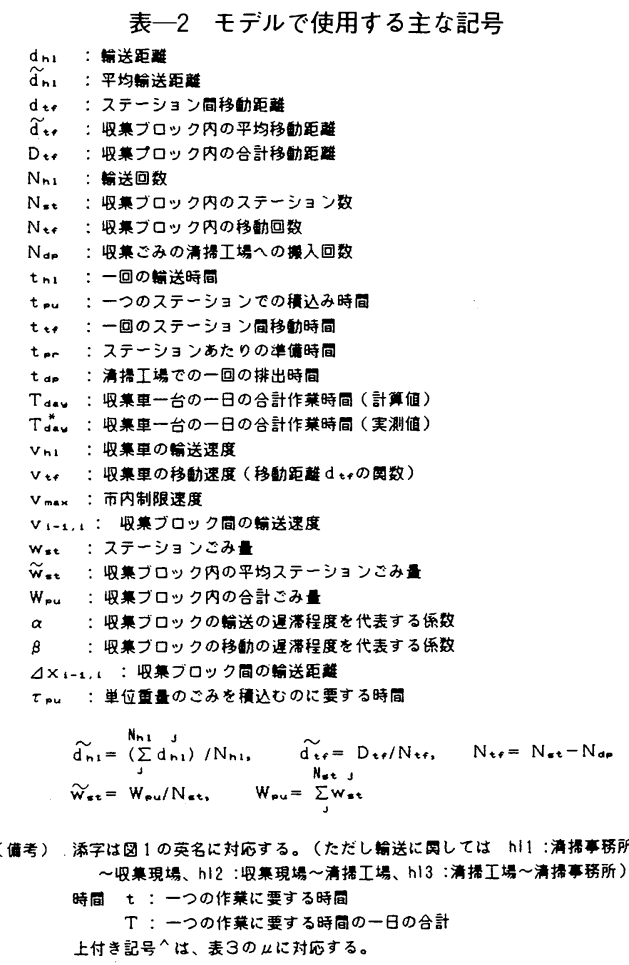

ば(bは各収集ブロックの特性を表わす量として, またC は実際の収集作業実績から各収集ブロックごとに得るこ とができる、そこで, 残る@のパラメーター（作業パラ メーター）值推定のため, 著者らは昭和 59 年 5 月, 図 -2 中(1) (4)で示す収集ブロックにおいて，収集車の追 跡調查を行った ${ }^{4)}$. 調査では, 1 日 1 台の収集車を特定し, 後方から追尾して図一1 に示す各単位作業時間およびス テーションごみ量, 輸送距離を測定した. 移動時の距離 は,ステーション位置を $1 / 1500$ の地図に記録しておき， 地図上で算出した。これを 5 日間（図一2(1)では 2 度） 行い, 収集ステーション数は 1 日 $35 \sim 55$, 計 217 か所 であった。なお，対象とした収集ブロックは，密集した アパート街, 一戸建て住宅地, 住宅が散在している地域, というように $\mathrm{N}$ 区内の典型的な住宅状況を反映するよう 選んだ。

調査は，主に場所的なばらつきの測定を実施したわけ であるが， $v_{h l}$ を除いて調査ブロック間で著しい違いが みられなかったため，地域によらない偶然要素としてと らえてよいと思われる. 表一3は，追跡調査で得た各パ ラメーターの度数分布 ${ }^{4}$ から決定した, 分布の平均值 $\mu$, 標準偏差 $\sigma$ である.ただし, $v_{t f}$ は距離 $d_{t f}$ の関数であっ て，図一3に示すように $\mu, \sigma$ を直線補間する.

\section{3. モデル式の精度に関する検討}

\section{（1）実測値との一致度合}

モデルの精度は，作業時間の実測値とモデルによる推

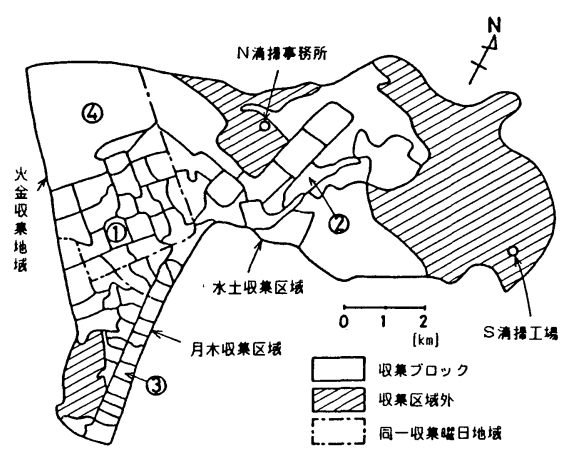

図一2 モデル対象地区概要

\begin{tabular}{|c|c|c|}
\hline 分布形 & パラメータ & $\sigma$ \\
\hline 正規分布 & $\begin{array}{ll}V_{n 1} & {[\mathrm{~km} / \mathrm{h}]} \\
V_{t f} & {[\mathrm{~km} / \mathrm{h}]} \\
t_{\text {pr }} & {[\mathrm{min}]} \\
t_{\text {dp }} & {[\mathrm{min}]}\end{array}$ & 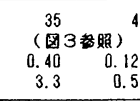 \\
\hline 对数正規分布 & $\tau_{\text {pu }}[\min / \mathrm{kg}]$ & 0.0063 \\
\hline
\end{tabular}

封数正規分布の磼密密度国数

$$
\mathrm{f}(\log x)=\frac{1}{\sqrt{2 \pi}(\log \sigma)} \text { exp }\left\{-\frac{(\log x-\log \mu)^{2}}{2(\log \sigma)^{2}}\right\}
$$


定値との一致度合をみることで検討できる，議論を簡単 にするため，表一3に示した作業パラメーターの $\sigma$ をす ベてゼロとし， $v_{h l}$ についても $\mu$ のみで代表させること にすると，モデルは表一1（II）のように簡略化できる（ $\sigma$ の影響については 4. で検討する). $\mu$ に対応する值を， 表一1中では上つきへをつけて示した。ただし，モデル （II）は平均値で代表させるモデルであるが，互いに独 立な確率変数 $\phi, \psi$ があってそれぞれ任意の分布に従う とき, その積 $\phi \cdot \psi$ の期待値（算術平均）はおのおのの 期待値の積であることを考えると， $\tau_{p u}$ の代表値として 対数平均を用いることは適当でない(追跡調査において, $w_{s t}$ と $\tau_{p u}$ は独立であることが羿められている4)．この ため, $\hat{\tau}_{p u}$ は表一3の $\mu, \sigma$ から理論的に算出される算術 平均值 0.00667 を用いる. また, このような処理により, 距離 $d_{h l}^{j}, d_{t s}^{j}$ を平均距離 $\tilde{d}_{h l}, \tilde{d}_{t s}$ (またはブロック内総 移動距離 $\left.D_{t j}\right)$, ステーションごみ量 $w_{s t}^{s}$ を収集ブロッ ク内平均ごみ量 $\widetilde{w}_{s t}$ (またはブロック内合計ごみ量 $W_{p u}$ ) で置き換えることができる（表一1（II），表一2中の式 参照). 他のパラメーターは, 追跡調査で得た值を用いる.

モデル（II）を用い, 追跡調査(1)〜(4)について計算し た作業時間を表一 4 に示す. $\varepsilon$ の定義は欄外に示したが, $\varepsilon<0$ とは, 計算值よりも実際にはもっと時間がかかっ ていたことを表わす.（）およびく>内の数值につ いては後述する.参考のため, 各収集ブロックのパラメー ターを最右欄に示した. なお， $d_{h l 3}=9 \mathrm{~km}$ である.

作業項目別にみると, $T_{p r}$ 以外は相対誤差 $\left|\varepsilon / T^{*}\right|$ が 大きく, $T_{d a y}$ の $\left|\varepsilon / T^{*}\right|$ も大きい収集ブロックがある. $T_{d p}$ の $\varepsilon$ が負となっている (2)(3)）のは, 数台の収集車 がほぼ同時に清掃工場に到着し，トラックスケールでの 計量を待たなければならなかったためであるが，その絶 対誤差 $|\varepsilon|$ は小さく, $T_{d a y}$ に及ぼす影響は小さい. (3) (4)にみられる $T_{p u}$ の誤差 $(\varepsilon<0)$ は, ごみをある程度 積むと収集車の押込板の回転が鈍るが，それでもなお積

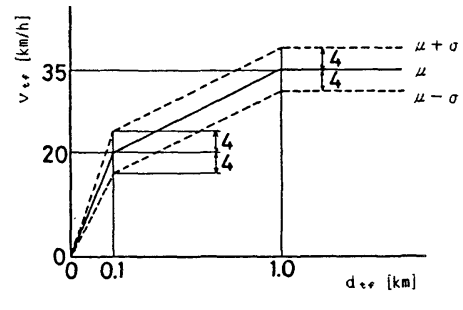

図一3 移動速度

込みを続けたために生じたものである゙1).これは，作業 の効率を考えるうえで重要な問題であるが, 収集車の構 造, ごみの大きさ・剛性により回転鈍化の開始時点が, また回転鈍化後，作業者がざこまで積込みを継続しよう とするかにより時間の遅れ度合が異なるため, モデル化 は今回見送った。

一方, $T_{h l 1}, T_{h l 2}, T_{h l 3}$ は $|\varepsilon|$ が大きく, これが $T_{d a y}$ の $|\varepsilon|$ を大きくする主要な原因となっている.これら をみると, 収集ブロックによって，また輸送区間によっ て $\varepsilon / T^{*}$ が異なっていることがわかるが, このことは地 区による交通状況の違いによって説明できる，たとえば $T_{h l 1}$ をとると, (3)は市中心部へ向かう交通量の多い道 路を通り, 信号待ち等で時間がかかり $(\varepsilon<0)$, (4)は往 来の少ない道路を通るためそのような遅れは少なく，両 者の $\varepsilon / T^{*}$ はかなり異なる. 清掃工場寄りの $6 \mathrm{~km}$ ほど の道は収集区域外で信号もなく，車の流れもスムーズな ため, $T_{h l 3}$ の $\varepsilon$ はすべて正である. $T_{h l 2}$ は前二者の中 間的な値となっている. また， $T_{t, f}$ のは $T_{h l}$ のそれと 相関が認められる.

(1)（4)のうち最も $T_{d a y}$ の誤差が大きいのは(3)であり $\varepsilon$ は一 36.5 にもなるが, そのうち $2 / 3$ が輸送, 移動に よるものである，図一7で後述するように，月木収集地 域ではこのように $|\varepsilon|$ の大きい収集ブロックが多く, $T_{d a y}$ の予測精度を向上させるには，交通状況の地域差

表一4 モデルによる計算俥と実測値の比較

\begin{tabular}{|c|c|c|c|c|c|c|c|c|c|c|c|c|c|c|c|c|}
\hline $\begin{array}{l}\text { 調㚗收集ブロッ } \\
\text { ク番号と項目 }\end{array}$ & \multicolumn{2}{|r|}{$T_{n+1}$} & \multicolumn{2}{|c|}{$\begin{array}{l}\text { 销送 } \\
T_{n 12}\end{array}$} & \multicolumn{2}{|c|}{$T_{n 13}$} & 积込み & \multicolumn{2}{|c|}{ 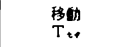 } & 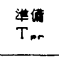 & $\begin{array}{l}\text { 排出 } \\
\text { Tan }\end{array}$ & \multicolumn{2}{|c|}{$\begin{array}{c}\text { 一日の作葉時国 } \\
\text { Tdav }\end{array}$} & \multicolumn{3}{|c|}{$\begin{array}{l}W_{s u} D_{11} d_{n 12} d_{n 12} \\
N_{2 t} N_{n 12} N_{n 12} N_{n 13} N_{a p}\end{array}$} \\
\hline (1) $\begin{array}{l}\mathrm{T}^{*}[\min \} \\
\mathrm{T}[\min ] \\
\varepsilon / \mathrm{T}^{*}[\%] \\
\sigma \pi / \mathrm{T}^{*}[\%]\end{array}$ & $\begin{array}{r}25.0 \\
15.8 \\
-36.8\end{array}$ & $\begin{array}{r}(20.0) \\
(-19.9) \\
\langle 4.3\rangle\end{array}$ & $\begin{array}{r}94.6 \\
88.5 \\
-6.4\end{array}$ & $\begin{array}{r}(100.7\rangle \\
\left(\begin{array}{r}6.5\rangle \\
\langle 2.0\rangle\end{array}\right.\end{array}$ & $\begin{array}{l}27.7 \\
30.9 \\
11.6\end{array}$ & $\begin{array}{l}\left(\begin{array}{r}29.8) \\
(7.7) \\
\langle 4.5\rangle\end{array}\right.\end{array}$ & $\begin{array}{r}47.5 \\
46.4 \\
-2.3 \\
\langle 5.8\rangle\end{array}$ & $\begin{array}{l}14.3 \\
13.0 \\
-9.4\end{array}$ & 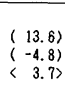 & $\begin{array}{r}13.2 \\
14.0 \\
6.0 \\
\langle 5.2\rangle\end{array}$ & $\begin{array}{c}8.4 \\
9.9 \\
17.8 \\
\langle 9.1\rangle\end{array}$ & $\begin{array}{r}230.7 \\
219.5 \\
-4.9\end{array}$ & $\begin{array}{l}(234.3) \\
\left(\begin{array}{l}1.6\rangle \\
\langle 1.6\rangle\end{array}\right.\end{array}$ & $\begin{array}{r}6960 \\
35\end{array}$ & 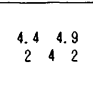 & $\begin{array}{l}12.9 \\
3\end{array}$ \\
\hline $\begin{array}{l}\mathrm{T}^{*}[\min ] \\
\mathrm{T}[\min ] \\
\varepsilon / \mathrm{T}^{*}[\%] \\
\sigma \mathrm{T} / \mathrm{T}^{*}[\%]\end{array}$ & $\begin{array}{r}6.9 \\
3.6 \\
-47.8\end{array}$ & $\begin{array}{r}(4.0) \\
(-41.7\rangle \\
\langle 7.4\rangle\end{array}$ & $\begin{array}{r}54.7 \\
53.5 \\
-2.2\end{array}$ & 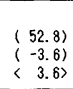 & $\begin{array}{r}29.8 \\
30.9 \\
3.7\end{array}$ & 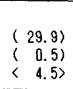 & $\begin{array}{r}50.3 \\
48.1 \\
-4.4 \\
\langle 5.2\rangle\end{array}$ & $\begin{array}{r}23.4 \\
20.3 \\
-13.1\end{array}$ & 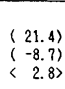 & $\begin{array}{r}21.0 \\
22.0 \\
4.8 \\
\langle 3.7\rangle\end{array}$ & $\begin{array}{r}12.1 \\
9.9 \\
-17.9 \\
\langle 8.1\rangle\end{array}$ & $\begin{array}{r}198.2 \\
188.3 \\
-5.0\end{array}$ & $\begin{array}{r}(187.6) \\
(-5.3) \\
\langle\quad 1.9\rangle\end{array}$ & $\begin{array}{r}7210 \\
55\end{array}$ & $\begin{array}{ccc}6.6 & 2.1 \\
1 & 4 & 2\end{array}$ & $3^{3.8}$ \\
\hline (44) $\begin{array}{l}\mathrm{T}^{*}[\min ] \\
\mathrm{T}[\min ] \\
\varepsilon / \mathrm{T}^{*}[\%] \\
\sigma_{+} / \mathrm{T}^{*}[\%]\end{array}$ & $\begin{array}{r}34.8 \\
28.8 \\
-17.2\end{array}$ & $\begin{array}{r}(27.5) \\
(-21.0) \\
\langle 2.8\rangle\end{array}$ & $\begin{array}{l}69.1 \\
76.1 \\
10.1\end{array}$ & $\begin{array}{r}(82.8) \\
\left(\begin{array}{r}19.9\rangle \\
\langle 2.0\rangle\end{array}\right.\end{array}$ & $\begin{array}{l}12.9 \\
15.4 \\
19.4\end{array}$ & $\begin{array}{l}\left\{\begin{array}{c}14.9) \\
(15.8) \\
\langle 6.1\rangle\end{array}\right.\end{array}$ & $\begin{array}{r}46.0 \\
39.6 \\
-14.0 \\
\langle 5.0\rangle\end{array}$ & $\begin{array}{r}37.3 \\
32.6 \\
-12.5\end{array}$ & $\begin{array}{r}(32.6) \\
(-12.7) \\
\langle 2.7\rangle\end{array}$ & $\begin{array}{l}22.8 \\
21.6 \\
-5.4 \\
\langle 4.1\rangle\end{array}$ & $\begin{array}{c}5.9 \\
6.6 \\
11.9 \\
\langle 10.9\rangle\end{array}$ & $\begin{array}{r}228.8 \\
220.7 \\
-3.5\end{array}$ & $\begin{array}{r}(225.6\rangle \\
(-1.4\rangle \\
\langle 1.5\rangle\end{array}$ & $\begin{array}{r}5940 \\
54\end{array}$ & $\begin{array}{cc}15.3 & 5.6 \\
3 & 3\end{array}$ & $2^{14.8}$ \\
\hline
\end{tabular}

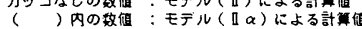
>內の组 


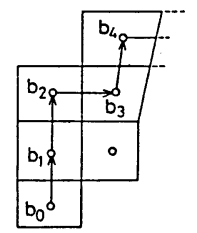

図一4 輸送の集中化

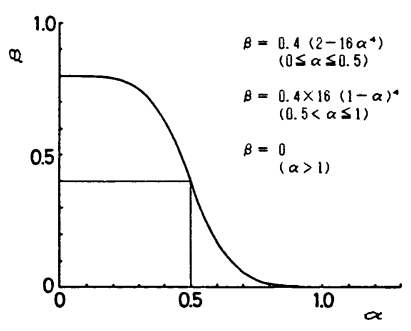

図一5 $\alpha$ と $\beta$ の関係

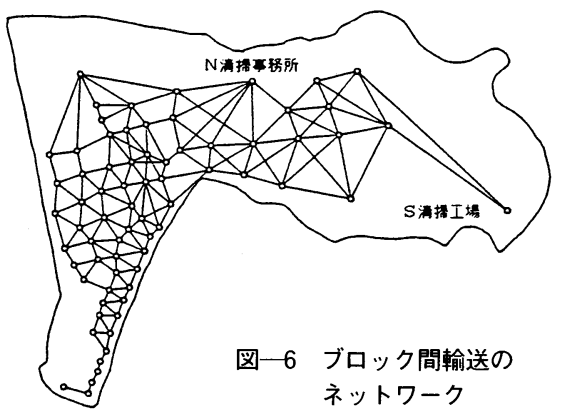

を考慮することが不可欠と思われる.

\section{（2）輸送，移動の遅滞係数 $\alpha, \beta$}

輸送に要する時間は, 経路に沿っての距離を $x$, 輸送 距離を $X$, 距離 $x$ における速度を $v(x)$ と書くと, $t_{h l}$ $=\int_{0}^{x}\{v(x)\}^{-1} d x$ で表わされるが, このような計算を行 うのは現実的ではない. そこで, 収集ブロック単位で距 離と速度を平均化し, 図一4のようにブロック番号 $b_{0}$ から $b_{k}$ への輸送を $b_{1}, b_{2}, \cdots, b_{k-1}$ を経由して行うと 考えると

$$
t_{h l}=\sum_{i=1}^{k} \frac{\Delta x_{i-1, i}}{v_{i-1, i}}
$$

のように書ける.ここで, $\Delta x_{i-1, i}, \quad v_{i-1, i}$ はそれぞれ収 集ブロック $b_{i-1}, b_{i}$ 間の距離および速度である. 輸送 に時間がかかるのは, 場所により $v_{i-1, i}$ が小さくなるた めであるから, 収集ブロックごとに輸送の遅滞程度を表 わす係数 $\alpha$ を考え

$$
v_{i-1, i}=\frac{1}{2}\left(\alpha_{i-1}+\alpha_{i}\right) v_{\max }
$$

$v_{\text {max }}:$ 市内制限速度

$\alpha_{i-1}, \alpha_{i}$ : 収集ブロック $b_{i-1}, b_{i}$ における $\alpha$

と表わすことにする. 清掃事務所, 清掃工場のある地区 も収集ブロックと同様に扱い， $\alpha$ を与える.

一方，追跡調査での観察によれば，ステーション間の 移動に時間がかかるのは， $v_{t s}$ がその収集ブロックにお いて全体的に低下するのではない，通常，輸送はブロッ ク内あるいはブロックに隣接した主要道路を通り, ブ ロック内の移動はその一部が輸送経路と重複するにすぎ ない. しかし，主要道路での交通が滞っていれば，移動 中の一時停止や, 主要道路を避けて迂回するためのU ターンの機会が増加し, その結果時間がかかる4). そこ で, 一時停止, $\mathrm{U}$ ターンの多さの程度を表わす係数 $\beta$ を用いて $t_{t s}$ を

$$
t_{t f}=\frac{\tilde{d}_{t f}}{\hat{v}_{t f}}(1+\beta)
$$

のように表わし, 十分なデータは得ていないが, 常識的 に $\alpha$ 大のとき $\beta \rightarrow 0, \alpha$ 小となると $\beta$ は急激に大きくな ると想像できるため, 図一 5 のような関係を仮定する.
ただし，この関係式は他の地域に関しては異なる可能性 がある.

モデル（II）中, $t_{h l}, t_{t f}$ を式（1）（ 3 ）で置換し， 輸送, 移動の遅帯を考慮したものをモデル $(I \alpha)$ とよぶ. すなわち, モデル（II $\alpha)$ とは, モデル（II）に交通事 情を表わすパラメーター $\alpha, \beta$ を加えたものである.

\section{（3） $\alpha$ 推定手順，およびそれによる精度向上}

モデル（I $\alpha)$ を最終的に収集地域全域に応用できる ものとするには，図一2の全収集ブロックにおける $\alpha$ を 推定することが必要となる. そこで2. ( 3 ) で求めた作 業パラメーター以外の, 計算に必要なパラメーターを以 下の手順で与える，ただし，各収集車はおのおのに割り 当てられた収集ブロックのみを収集したとの仮定をお $<$.

輸送経路については,まず収集ブロックに番号をつけ， 隣接する収集ブロックの中心間距離（式（１）の $\Delta x_{i-1, i}$ ) を，道路網に沿って地図上で測定しておく．これにより 図一6に示すようなネットワークが得られる. 次に，各 収集ブロックごとに，清掃事務所，清掃工場までの経路 （経由する収集ブロックの順番）を追跡調査による著者 らの経験および清掃事務所での聞き取りに基づいて与え ておき，計算においてはこの経路を順次たどっていく.

$N_{s t}, \tilde{d}_{t f}\left(D_{t f}\right)$ は, 清掃事務所で業務管理に用いてい るステーション位置, 収集経路を記入した地図より求め ることができる、 $\widetilde{w}_{s t}\left(W_{p u}\right)$ は，昭和 59 年 9 月（S市 の場合年平均に近い) の各収集車の実績値を用いた.

1 日の実作業時間 $T_{d a y}^{*}$ ，および $N_{h l 1}, N_{h l 2}, N_{h l 3}, N_{d p}$ は, 同日の収集車のタコグラフ, 作業記録から読み取っ た。ただし，各収集曜日地域において，最も清掃工場か ら遠いいくつかの収集ブロックの収集車は，担当分のご み収集を午前中に終了し，午後は作業時間の公平のため 他収集車の積込み作業を手伝っており，午後の作業の輸 送距離などが明確にとらえられない。そのため，これら のものについては午前の作業のみをデー夕とした。式 ( 2 ) の $v_{\max }$ は $40 \mathrm{~km} / \mathrm{h}$ とする.

以上のデータを用いて，モデル $(\Pi \alpha)$ により全収集 ブロックそれぞれの $T_{d a y}$ を計算し， $T_{d a y}^{*}$ と比較する. 
最初に $\alpha$ を一律に $0.875(=35 / 40)$ とし，輸送，移動 の地域差を考慮しないときの結果を図一7(a) に示す.

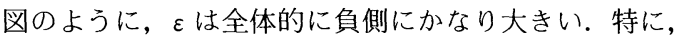
清掃工場から遠い月木収集地域の誤差が大きいが， $\alpha$ を もっと小さくしても地域間の $\varepsilon$ の差は変わらず， $\alpha$ を一 定とはし得ないことがわかる.

さて，図一7(a) の $\varepsilon$ を全収集ブロックにわたって小 さくするには，収集ブロックの数だけの $\alpha$ を未知パラ メーターとする $\Sigma \varepsilon^{2}$ の最小化問題を解けばよいが，そ れにより現実的に満足のいく解を得ることはほとんど期 待できない，そこで，隣接したブロックでは $\alpha$ が大き く違わないことを原則とし，各ブロックの交通状況に関 する情報（特にブロック間の相対的な違いについての経 験）をもとに， $\alpha$ を試行錯誤的に与えた。ただし， $\alpha$ は 簡単のため 0.1 きざみとし，最終的に図一 8 のように定 めた。このときの計算結果を図一 7 (b) に示すが， $\alpha$ を 一定とした図一7(a) に比べてかなりの向上がみられる. 全収集ブロックの $|\varepsilon|$ の平均值は 20.1 から 10.6 に減 少した. 参考のため, 追跡調査地区についてモデル $(\Pi \alpha)$
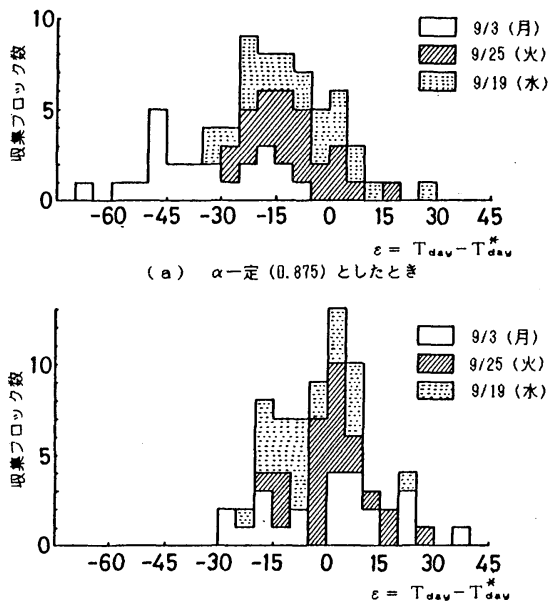

（b） aに地域差を与えたとき

図一7 モデルの誤差

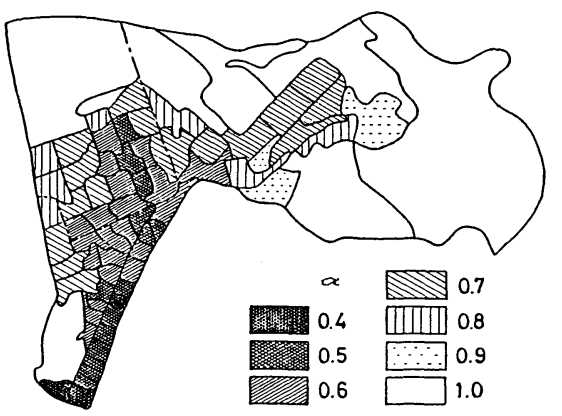

図一8 各収集ブロックの $a$
で計算した結果を表一 4 の（）内に示す $(\alpha$ を変える ことで差が生じるのは輸送と移動のみである)，一部で 逆に誤差の大きくなったものもみられるが，全体として $\varepsilon$ は改善されている.

誤差を完全には解消できない理由としては，まず積込 み，排出の遅れをモデル化していないことがある.また， 輸送経路に関する著者らの仮定と実際との相違，作業班 の相互応援による収集経路の変更などを正確に把握でき なかったことも，誤差を大きくする原因である．特に， 作業の応援は収集システムに柔軟性を与える手段として 頻繁に行われており，記録のうえからその内容を知るこ とは難しいが，詳細なデータが得られればよりよい適合 度が期待できる。なお， $T_{t f}$ の全体に占める割合が小さ いこともあって，図一 5 に示した $\alpha$ と $\beta$ の関係式を变更 することの影響はわずかであった。

また， $\alpha$ を信号の数，道路幅，交通量などと関連づけ るか，あるいは実際に何らかの測定を行って推定するこ とも考えられるが，著者らが行ったように地域の交通事 情に関する経験に基づいて決めるのが，最も効率のよい 現実的な方法と思われる。

\section{4. 作業パラメーターのランダムさの影響}

\section{（1）確率分布に従う作業パラメーターの発生方法}

前章では作業パラメーターのランダムさを無視して議 論を進めたが，それらがざの程度作業時間に影響を及ほ すのかを検討しておく必要がある，計算機において，確 率分布は乱数を用いることで再現できる．これはモンテ カルロ法とよばれる手法であるが, 基本となる一様乱数 はいくつかの検定 ${ }^{5)}$ を行った結果

$$
\left.\begin{array}{l}
u_{i+1}=5^{11} u_{i} \quad\left(\bmod 2^{31}\right) \\
\theta_{i+1}=u_{i+1} / 2^{31}
\end{array}\right\}
$$

を使用することにした．ここで， $u$ は整数， $\theta$ は $[0,1]$ の一様乱数である. 中心極限定理を応用することにより 正規乱数（発生頻度が正規分布に従う乱数）が得られ， 表一3の $\mu, \sigma$ に応じて各作業パラメータ一值を算出す る. 収集ブロック間の輸送速度 $v_{i-1, i}$ は, 表一3で示し た $v_{h l}$ と同じ標準偏差 $\sigma=4$ をもつとした。

\section{(2) 計算結果}

ランダムさの影響度合は, 1 日分の計算を多数回繰り 返し, 各時間の分散をみることで評価できる.モデル ( I ) の $t_{h l}^{j}$ を式 (1), (2) で， $t_{t s}^{j}$ を

$$
t_{t s}^{j}=\frac{d_{t s}^{j}}{v_{t s}^{j}}(1+\beta)
$$

で置き換え，輸送と移動の遅滞を考慮したものをモデル （I $\alpha$ ）とよび，計算はこれによって行う（表一1参照）. ここで, 各作業パラメーターはjで示されるおのおの の作業回数（ただし輸送については $N_{h l} \times k$ 回）だけ正 


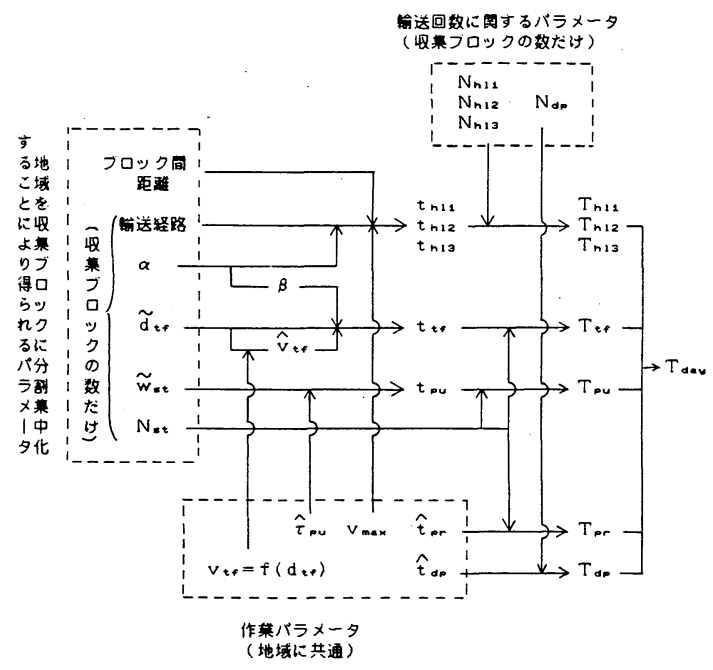

図一9 モデル（I $\alpha)$ による 1 台の収集車の 1 日の作業時間の 計算手暊

規乱数から発生させ, $w_{s t}^{j}, d_{t s}^{j}$ は追跡調査の実測値をそ のまま用いる.

表一4 中 $<>$ \に示すのは, 各調査収集ブロックに 対し 100 日分の計算を行い, 100 回の時間の標準偏差 $\sigma_{T}$ を求め, $\sigma_{T} / T^{*}$ として表わしたものである. なお当然 ながら, 平均値はモデル $(\Pi \alpha)$ の計算值と一致した. $\varepsilon / T^{*}$ と $\sigma_{T} / T^{*}$ を比較して明らかなように, ランダム な要素による計算値の変動幅はそれほど大きくない。し たがって, 作業パラメーターは平均值を用いればよく, モデルは $(\Pi \alpha)$ で十分と思われる.

モデル $\left(\prod \alpha\right)$ により 1 台の収集車の 1 日の作業時間 $T_{d a y}$ を計算する手順を, 図一9に整理する.

\section{5. 作業手順に関する判断を含むモデルとその 計算例}

これまでの検討により, 収集ブロックが固定され，輸 送回数に関するパラメーターが与えられれば, 1 日の作 業時間 $T_{d a y}$ を推定することができる. しかし, 計画段 階においては対象地域の地理的条件, 収集すべきごみ量 の分布, 交通条件のもとで, いかにして各収集車の担当 区域を決定するか（収集ブロック構成）が第一の問題で あり， $T_{d a y}$ はその際の重要な指標である，収集作業を 進めるときには, 収集車内のごみ積込み状況, 時間の経 過に応じて, 収集を継続するか, 処理場へ輸送するか等 の判断が伴う. 収集ブロックが定められればその判断に 従って作業が進められ, 結果として輸送回数パラメ一 ターおよび $T_{\text {day }}$ が定まる. したがって, 作業時のそう した判断をプログラム化すれば， $T_{d a y}$ のモデル式を用 いて収集輸送作業をシミュレートでき, 計画への応用が
可能となる.

ここでは,「試行的なブロック割当てを行って収集作 業を実施し，作業者の意見をフィードバックしながら各 収集車の作業時間のアンバランスを解消するよう修正し ていく」という現実の収集ブロック決定法を踏まえ, そ れを計算機で行う例を示す。このモデルは収集条件のさ まざまな変化に対応できるが, 計算例として, 収集体制 の変更の中でも, 特別な施設や機材を必要とせずに計画 面だけの考慮で済む，という意味で比較的実施の容易な 収集頻度の変更を取り上げ，検討を行う。もちろん，作 業の平均化のため 1 台の収集車の担当区域を処理場まで の距離が異なる複数区域とする,などの複雑な計画も考 えられるが，その際には，判断基準を追加・修正すれば よい.

（1）収集作業における判断アルゴリズム

著者らは追跡調査での経験, 清掃事務所での聞き取り, および作業記録の詳細な検討により，図一10に示す判 断基準を考えた. 収集作業の実施において，作業者はそ の経験をもとに最も効率的な方法を見出していると考え られ，図一10はその平均的な判断を表現したものであ る.この特徴は, 午前と午後で時間に対する判断が異な ることであり，要約すると次のようになる．「午前の作 業は時間にそれほどとらわれず，収集車が満載となるま で収集を続けるが, 午後は作業の公平感のため, 終了時

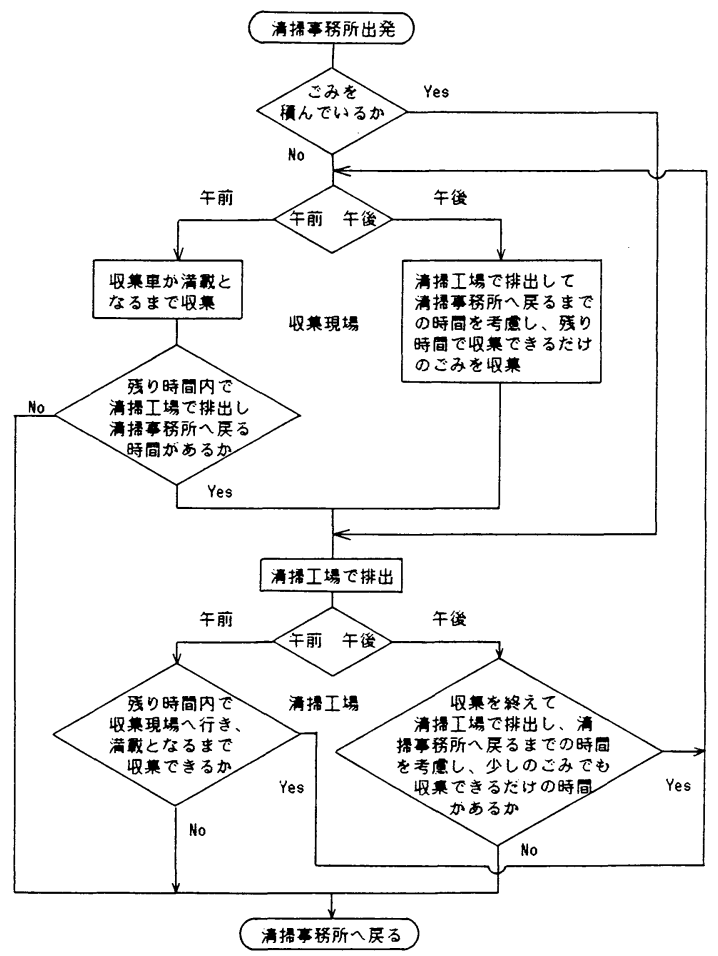

図一10 収集作業における判断アルゴリズム 
刻が同じになるよう作業が行われる。また，現場での収 集後, 午後は必ず清掃工場で排出するが，午前は時間が なければそのまま昼食のため清掃事務所へ戻る」.

収集車が満載となったかどうかを判定する值を可能積 載量とよび, $R_{p u}$ と書く.

\section{（2）収集ブロックの決定方法}

定められた時間内で効率よくごみを収集するにはどの ような収集ブロックを構成するのがよいかは，興味ある 問題であるが，ここでは次のような計算を行う.

いま，現行の収集ブロックを図一6のように集中化し (単位作業時間 $t_{h l}, t_{t s}, t_{\rho u}, t_{\rho r}$ (図一9) が集中点に対 応して決まる),地域の連続性を考虑して隣接するブロッ ク順に番号をつける. そして，1台の収集車の収集が近 接したステーション間で実施されるという現状のブロッ ク分割法を踏襲し，1つのブロック内のステーションの 収集が終われば次のブロック内のステーションに移ると 考える(ブロック順はたとえば図一11のようであり， この条件のもとで, 番号のつけ方を変更して計算を行っ たが，以下の計算結果はほとんど影響を受けない).

以上の準備を行ったのち, 1 台の収集車が最も若い番

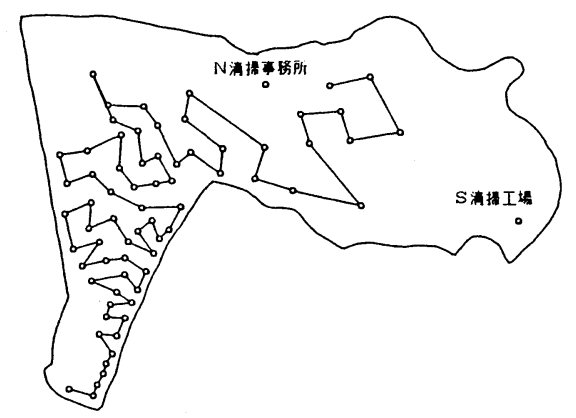

図一11 集中化ブロックの収集順

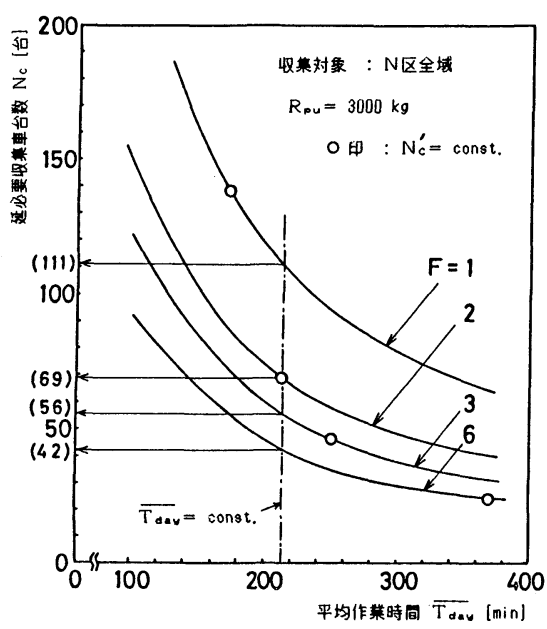

図一12 収集頻度変更時の必要収集車台数と平均作業時間
号の収集ブロック内のステーションから収集を開始し， 1 日の作業時間に上限を設けて図一10のアルゴリズムに 従って収集を行うと，その時間内で収集できるステー ション数が算出される. すなわちブロックの再構成がで き, 同時にその収集車の作業時間, 輸送回数が得られる. この計算を, 順次収集車を更新し, 対象地域の全ごみが 収集されるまで続けると, 収集車の延必要台数 $N_{c}$ ，お よびその平均作業時間 $\overline{T_{d a y}}$ が求まる. 時間の制約を定 めても清掃工場への般入回数が整数值であるため, $T_{d a y}$ は 1 時間，あるいはそれ以上の幅をもってばらつく．そ のため, 作業時間は平均值で代表させる.

\section{（3）収集頻度変更に関する検討}

収集頻度を変更すると, 収集日に収集すべきごみ量も 変化する. 収集頻度が増すとごみの絶対量も増える ${ }^{6)}$, ごみの発生量が曜日によって異なるわなどの知見もある が，ここでは簡単のため, 頻度を変えてもごみの総量は 同じで，毎日均等に発生し，各収集日には前収集日から の日数分だけが排出される，と仮定する．すると，収集 頻度が $F$ 回/週 $(F=1,2,3,6)$ のときの 1 週間におけ る最大収集量は $(1+6 / F)$ 日分のごみ量となる. 3. ( 3 ) で用いた昭和 59 年 9 月の各収集ブロックのごみ量を, この比に応じて変えて計算を行ったところ, 図一12に 示す結果を得た。ただし，頻度変更には収集曜日による 地域割りの変更も伴うため，N区全域を収集するとして 計算しており，追跡調査において収集車が $3000 \mathrm{~kg}$ を 超えるあたりから，押込板の回転鈍化が認められたた $\bigotimes^{4)}, R_{\rho u}=3000 \mathrm{~kg}$ とした. 図の曲線は，1 日 1 台当た りの作業時間を長くするよう計画すれば，所要台数が少 なくなることを示している.

収集頻度 $F$ の場合, 全地域を $6 / F$ 日間で収集するこ とになるので，実際に必要となる収集車は $N_{c}^{\prime}=N_{c} /$ $(6 / F)$ 台である. 図一12において, 現状の $F=2$ で $N_{c}^{\prime}=23$ にあたる $\overline{T_{a d a}}$ をとって比較すると, 必要な台数 $N_{c}^{\prime}$ は $19(F=1), 28(F=3), 42(F=6)$ となる. また，見方を変えて収集車台数を $N_{c}^{\prime}=23$ に固定すると， 作業時間は図一12中○印で示された点となる。なお, 与えたごみ量に対し図一12で得られた $\overline{T_{\text {day }}}$ は, タコグ ラフから読み取った $T_{a a y}^{*}$ とよく一致しており, 本計算 は妥当であったと思われる.

この例では, 1 回に収集するごみ量の変化という収集 頻度変更の一面のみを取り上げたにすぎないが, 頻度を 増すにつれて収集ごみの面積密度が低下し，それによる 収集効率の低下が収集車台数の増大として示された。

ここに示した応用のほかに，このモデルは渋滞を避け るための収集時間帯の変更や, 清掃工場位置の変更, 中 継基地を設けて輸送時間の短縮をはかる中継輸送の導 入，などの問題の検討に用いることができる. 


\section{6. ま と め}

本論文の主要な結論を，以下にまとめる.

a) 1 台の収集車の 1 日の作業時間を推定するモデル 式の精度を主として左右するのは, 輸送および移動時間 の誤差である.

b）輸送，移動の遅滞の度合を表わす係数 $\alpha, \beta$ を考 慮に入れることで, モデル式の精度は向上した.

c) 作業パラメーターのもつランダムさの影響は小さ く, 平均值を用いても構わない. 最終的に得られたモデ ル式は，パラメーターを集中化あるいは平均値で代表さ せたモデル（

こうして，モデル式を作成するうえで考慮すべき主要 な点を指摘し，その作成手順を示した。ささら

d）収集作業遂行時に時間, 収集車の積載量に関して 下される判断をプログラム化し, 作業の進行をシミュ レートして収集ブロックを自動的に再構成するモデルを 作った。 また，その計算例を示した。

今回得られたモデルをもとに，さらに検討を進めてシ ステムの構造を解明し，より簡便なモデルを作成して， かつ応用の可能性を広げることが著者らの次の目標であ る.
最後に, 当講座技官の松尾孝之氏, 当時大学院学生で あった茂泉博史氏のご協力に謝意を表します.

\section{参 考 文 献}

1) Quon, J.E. et al. : Simulation and analyses of a refuse collection system, Proc. of ASCE, Vol.91, No.SA5, pp. 17 -36, Oct., 1965.

2) Truitt, M. M. et al. : Simulation model of urban refuse collection, Proc. of ASCE, Vol.95, No. SA2, pp.289 298, Apr., 1969.

3) Quon, J.E. et al. : Simulation model of refuse collection policies, Proc. of ASCE, Vol. 95, No. SA3, pp. 575 〜592, Jun., 1969.

4）松藤敏彦ほか：都市ごみステーション収集の追跡調査に ついて, 都市清掃, Vol.38, No.147, pp. 38 46, 1985.

5) 宮武 修・脇本和昌：乱数とモンテカルロ法, 森北出版, pp. 12 13, 36 39, 1979.

6）中杉修身ほか：一般廃棄物原単位の推定方法について, 第 5 回全国都市清掃研究発表会講演論文集, pp. 63 66, 1984.

7）松藤敏彦ほか：都市ごみ収集量の変動に関する研究，第 40 回土木学会年次学術講演会概要集 (II ), pp. 663 664, 1985.

(1985.12.20 - 受付) 